\title{
Anxiety among Patients Visiting for Periodontal Therapy in a Tertiary Care Dental Hospital: A Descriptive Cross-sectional Study
}

\author{
Bhagabat Bhattarai, ${ }^{2}$ Sujaya Gupta, ${ }^{1}$ Sirjana Dahal, ${ }^{2}$ Deepak Kumar Roy, ${ }^{3}$ Saroj Pant, ${ }^{1}$ Rachana Karki, ${ }^{1}$ Tanu \\ Thakuri $^{1}$ \\ 'Department of Periodontics and Oral Implantology, Kathmandu Medical College, Bhaktapur, Nepal, ${ }^{2}$ Dentistry, \\ Institute of Medicine, Maharajguni, Kathmandu, Nepal, ${ }^{3}$ Department of Conservative Dentistry and Endodontics, \\ Kathmandu Medical College, Bhaktapur, Nepal.
}

\section{ABSTRACT}

Introduction: The aetiological factors of dental fear include negative information, witnessing or having a bad experience, and negative conditions related to periodontal treatment. Modified Dental Anxiety Scale Nepali version, is one of the tools used in epidemiological studies to measure dental anxiety in adults. The objective was to find out the prevalence of anxiety among dental patients visiting for periodontal therapy in a tertiary care hospital.

Methods: This descriptive cross-sectional study was conducted among patients visiting for periodontal therapy from November 2020 to January 2021 at a tertiary care dental hospital. Ethical clearance from Institutional Review Committee (Reference no. 0311202001) was taken before the study. Convenient sampling was done. A standard questionnaire for dental anxiety was used for data collection after receiving informed consent from the participants. Data were entered and analyzed in Microsoft Excel Sheet. Descriptive data are presented as means, standard deviations, frequencies, and percentages.

Results: Among a total of 311 participants visiting for periodontal therapy, 297 (95.49\%) (92.57-97.42 at $95 \%$ Confidence Interval) were having anxiety. Among total patients, $113(36.33 \%)$ were fairly anxious, 111 (35.69\%) were slightly anxious, 62 (19.94\%) very anxious and 11 (3.54\%) were extremely anxious. Majority of males $54(17.36 \%)$ were slightly anxious while most females $67(21.54 \%)$ were fairly anxious. Mean Modified Dental Anxiety Scale-Nepali score of all the participants was 11.59 \pm 3.808 . Extreme dental anxiety was observed in 11 (3.54\%) participants 7 (2.25\%) females; 4 $(1.29 \%)$ males).

Conclusions: The prevalence of anxiety among patients visiting for periodontal therapy in this study was found to be higher compared to other study done in similar setting.

Keywords: bone drilling; local anaesthetics; Nepal; scaling; tooth drilling.

\section{INTRODUCTION}

Dental anxiety persists among patients despite increased awareness about preventive approaches to oral diseases and innovations in pain reduction. ${ }^{1,2}$ Studies have shown $13 \%$ of patients in dental college and $20.90 \%$ in dental clinics were severely anxious. ${ }^{3} \mathrm{~A}$ telephone survey showed that $11.6 \%$ had high dental anxiety with female being more anxious. ${ }^{4}$ This was similar to some studies ${ }^{5,6}$ but not all. ${ }^{7}$
The aetiological factors of dental fear include negative information, witnessing or having bad experience and negative condition related to periodontal treatment. ${ }^{8}$ Lack of adequate dental health education may result in a high level of dental anxiety. ${ }^{9}$ Although none of existing

Correspondence: Dr. Bhagabat Bhattarai, Department of Periodontics and Oral Implantology, Kathmandu Medical College, Bhaktapur, Nepal. Email: bhattarai_5@hotmail.com, Phone: +977-9849529947. 
psychometric tests are regarded as gold standard, Corah's Dental Anxiety Scale (DAS), Modified Dental Anxiety Scale (MDAS), and Kleinknecht's Dental Fear Survey are most commonly used to measure dental anxiety in adults. ${ }^{10}$

The objective was to find out the prevalence of anxiety among patients visiting for periodontal treatment in a tertiary care hospital.

\section{METHODS}

This descriptive cross-sectional study was conducted in the Kathmandu Medical College (KMC), Teaching Hospital, Nepal. The data were collected from outpatient dental departments of both Kathmandu and Bhaktapur hospitals of KMC from November 2020 to January 2021 after obtaining ethical clearance from institutional review committee of KMC (Ref. 0311202001). Patients visiting for periodontal therapy were requested to participate in the study by convenience sampling. A standard questionnaire was taken from Giri, et al. ${ }^{11}$ study which was distributed among all the patients intended for periodontal therapy and after showing their willingness for participation in the study. An informed consent was obtained from the participants before they were given the questionnaire. The questionnaire contained questions about all the possible dental procedures. Patients not willing for periodontal therapy and under psychiatric consultation or under psychiatric medication were excluded from the study. Convenient sampling was done. A sample size of 311 was calculated by using following formula:

$$
\begin{aligned}
& \mathrm{n}=\mathrm{Z}^{2} \times \mathrm{p} \times \mathrm{q} / \mathrm{e}^{2} \\
& =(1.96)^{2} \times(0.74) \times(1-0.74) /(0.05)^{2} \\
& =295.65
\end{aligned}
$$

Adding $5 \%$ of non-response rate, total sample was $310.43 \approx 311$. Data were entered and analysed in Microsoft Excel sheet. Descriptive findings are

\begin{tabular}{|c|c|c|c|c|c|c|}
\hline Questions & $\begin{array}{l}\text { Not } \\
\text { anxious n } \\
(\%)\end{array}$ & $\begin{array}{l}\text { Slightly } \\
\text { anxious } \\
\mathrm{n}(\%)\end{array}$ & $\begin{array}{l}\text { Fairly } \\
\text { anxious n } \\
(\%)\end{array}$ & $\begin{array}{l}\text { Very anxious } \\
\text { n (\%) }\end{array}$ & $\begin{array}{l}\text { Extremely } \\
\text { anxious } n \\
(\%)\end{array}$ & Mean \pm SD \\
\hline $\begin{array}{l}\text { If you went to your dentist } \\
\text { for treatment tomorrow, how } \\
\text { would you feel? }\end{array}$ & $85(27.33)$ & $\begin{array}{l}137 \\
(44.05)\end{array}$ & $71(22.83)$ & $14(4.50)$ & $4(1.29)$ & $2.08 \pm 0.890$ \\
\hline $\begin{array}{l}\text { If you were sitting in the } \\
\text { waiting room (waiting for } \\
\text { treatment), how would you } \\
\text { feel? }\end{array}$ & $\begin{array}{l}113 \\
(36.33)\end{array}$ & $\begin{array}{l}117 \\
(37.62)\end{array}$ & $70(22.51)$ & $11(3.54)$ & - & $1.93 \pm 0.853$ \\
\hline $\begin{array}{l}\text { If you were about to have a } \\
\text { tooth drilled, how would you } \\
\text { feel? }\end{array}$ & $30(9.65)$ & $\begin{array}{l}116 \\
(37.30)\end{array}$ & $84(27.01)$ & $60(19.29)$ & $21(6.75)$ & $2.76 \pm 1.081$ \\
\hline $\begin{array}{l}\text { If you were about to have } \\
\text { your teeth scaled and } \\
\text { polished, how would you } \\
\text { feel? }\end{array}$ & $\begin{array}{l}124 \\
(39.87)\end{array}$ & $\begin{array}{l}119 \\
(38.26)\end{array}$ & $43(13.83)$ & $20(6.43)$ & $5(1.61)$ & $1.92 \pm 0.967$ \\
\hline $\begin{array}{l}\text { If you were about to have a } \\
\text { local anaesthetic injection in } \\
\text { your gum, above an upper } \\
\text { back tooth, how would you } \\
\text { feel? }\end{array}$ & $34(10.93)$ & $\begin{array}{l}96 \\
(30.87)\end{array}$ & $81(26.05)$ & 69 (22.19) & 31 (9.97) & $2.89 \pm 1.166$ \\
\hline Total & $14(4.50)$ & $\begin{array}{l}111 \\
(35.69)\end{array}$ & $\begin{array}{l}113 \\
(36.33)\end{array}$ & 62 (19.94) & $11(3.54)$ & \\
\hline
\end{tabular}
presented as means, standard deviations, frequencies, and percentages.

\section{RESULTS}

Among total 311 participants, 297 (95.49\%) (92.5797.42 at $95 \%$ Confidence Interval) were having anxiety. Among the total 311 participants, 113 (36.33\%) were fairly anxious and $111(35.69 \%)$ were slightly anxious (Table 1). 


\begin{tabular}{|c|c|c|c|c|c|c|}
\hline MDAS scores & $\begin{array}{l}\text { Not anxious } \\
(0-5) \text { n (\%) }\end{array}$ & $\begin{array}{l}\text { Slightly } \\
\text { anxious (6-10) } \\
\text { n (\%) }\end{array}$ & $\begin{array}{l}\text { Fairly anxious } \\
(11-14) \text { n (\%) }\end{array}$ & $\begin{array}{l}\text { Very anxious } \\
(15-18) \text { n (\%) }\end{array}$ & $\begin{array}{l}\text { Extremely } \\
\text { anxious (19- } \\
25) \text { n (\%) }\end{array}$ & Total n (\%) \\
\hline \multicolumn{7}{|l|}{ Sex } \\
\hline Male & $9(2.89)$ & $54(17.36)$ & $46(14.79)$ & $30(9.65)$ & $4(1.29)$ & $143(45.98)$ \\
\hline Female & $5(1.61)$ & $57(18.33)$ & $67(21.54)$ & $32(10.29)$ & $7(2.25)$ & $168(54.02)$ \\
\hline \multicolumn{7}{|c|}{ Age categories (years) } \\
\hline $0-19$ & $1(0.32)$ & $8(2.57)$ & $13(4.18)$ & $5(1.61)$ & $3(0.96)$ & $30(9.65)$ \\
\hline $20-34$ & $4(1.29)$ & $43(13.83)$ & $50(16.08)$ & $29(9.32)$ & $3(0.96)$ & $129(41.48)$ \\
\hline $35-49$ & $4(1.29)$ & $35(11.25)$ & $29(9.32)$ & $13(4.18)$ & $2(0.64)$ & $83(26.69)$ \\
\hline $50-64$ & $4(1.29)$ & $12(3.86)$ & $14(4.50)$ & $12(3.86)$ & $2(0.64)$ & $44(14.15)$ \\
\hline$\geq 65$ & $1(0.32)$ & $13(4.18)$ & $7(2.25)$ & $3(0.96)$ & $1(0.32)$ & $25(8.04)$ \\
\hline Total & $14(4.50)$ & $111(35.69)$ & $113(36.33)$ & $62(19.94)$ & $11(3.54)$ & 311 \\
\hline
\end{tabular}

The mean MDAS-N score of all the participants was The mean MDAS-N score of all the participants was $11.59 \pm 3.808(\mathrm{SEM}=0.216$; minimum $=5$; maximum $=21$, Table 3).
A cut-off value of 19 and above has been determined empirically ${ }^{4}$ to indicate extreme dental anxiety that may require special attention. Extreme dental anxiety (MDAS-N $\geq 19$ ) was observed in 11 (3.54\%) of the 311 participants (Table 3 ). Among them, 7 (2.25\%)

\begin{tabular}{|c|c|c|c|c|}
\hline Anxiety categories & $\begin{array}{l}\text { Moderate to high } \\
\text { ( } \leq 18 \text { MDAS-N) }\end{array}$ & $\begin{array}{l}\text { Extreme ( } \geq 19 \\
\text { MDAS-N) }\end{array}$ & Mean \pm SD & n (\%) \\
\hline \multicolumn{5}{|l|}{ Sex } \\
\hline Male & 139 (44.69) & $4(1.29)$ & $11.32 \pm 3.957$ & $143(45.98)$ \\
\hline Female & $161(51.77)$ & $7(2.25)$ & $11.82 \pm 3.673$ & $168(54.02)$ \\
\hline \multicolumn{5}{|l|}{$\begin{array}{l}\text { Age categories } \\
\text { (years) }\end{array}$} \\
\hline $0-19$ & $27(8.68)$ & $3(0.96)$ & $12.43 \pm 3.830$ & $30(9.65)$ \\
\hline $20-34$ & $126(40.51)$ & $3(0.96)$ & $11.91 \pm 3.596$ & $129(41.48)$ \\
\hline $35-49$ & $81(26.05)$ & $2(0.64)$ & $10.96 \pm 3.830$ & 83 (26.69) \\
\hline $50-64$ & $42(13.50)$ & $2(0.64)$ & $11.93 \pm 4.201$ & $44(14.15)$ \\
\hline$\geq 65$ & $24(7.72)$ & $1(0.32)$ & $10.40 \pm 3.797$ & $25(8.04)$ \\
\hline Total & $300(96.46)$ & $11(3.54)$ & $11.59 \pm 3.808$ & 311 \\
\hline
\end{tabular}

females and $4(1.29 \%)$ males had extreme anxiety level (Table 3). At the threshold value of 19 and above, a dental professional should consider using additional management approaches like relaxation, systematic desensitisation or adjunctive pharmacotherapy.

The youngest age group of 0-19 years had highest mean score of $12.43 \pm 3.830$ (Table 3). The mean MDAS-N score was found highest $(11.83 \pm 3.774)$ among bachelors and above education group, but the difference was minimal (Table 4). The majority of the patients $(118,37.94 \%)$ had an education of bachelors and above (Table 4). Regarding occupation, most of the participants $(75,24.12 \%)$ were students followed by homemaker $(68,21.86 \%)$ and MDAS-N score, was also highest $(12.51 \pm 3.663)$ in the student group, (Table 4). The "Others" category of occupation included: artist (1), engineer (1), NGO worker (1), policeman (1), reporter (1), sportsman (1), and writer (1). 
Bhattarai et al. Anxiety among Patients Visiting for Periodontal Therapy in a Tertiary Care Dental Hospital: A Descriptive...

\begin{tabular}{|c|c|c|c|c|c|c|c|}
\hline $\begin{array}{l}\text { Anxiety } \\
\text { categories/ } \\
\text { MDAS-N } \\
\text { scores }\end{array}$ & $\begin{array}{l}\text { Not } \\
\text { anxious } \\
(0-5)\end{array}$ & $\begin{array}{l}\text { Slightly } \\
\text { anxious (6- } \\
10)\end{array}$ & $\begin{array}{l}\text { Fairly } \\
\text { anxious (11- } \\
14)\end{array}$ & $\begin{array}{l}\text { Very } \\
\text { anxious (15- } \\
18)\end{array}$ & $\begin{array}{l}\text { Extremely } \\
\text { anxious (19- } \\
25)\end{array}$ & Mean \pm SD & Total \\
\hline \multicolumn{8}{|l|}{ Education } \\
\hline Grade $0-5$ & $1(0.32)$ & $21(6.75)$ & $23(7.40)$ & $12(3.86)$ & $1(0.32)$ & $11.69 \pm 3.619$ & $58(18.65)$ \\
\hline Grade $6-10$ & $3(0.96)$ & $24(7.72)$ & $16(5.14)$ & $10(3.22)$ & $5(1.61)$ & $11.41 \pm 4.329$ & $58(18.65)$ \\
\hline $\begin{array}{l}\text { Grade } 11- \\
12\end{array}$ & $6(1.93)$ & $16(5.14)$ & $26(8.36)$ & $14(4.50)$ & $1(0.32)$ & $11.46 \pm 3.805$ & $63(20.26)$ \\
\hline $\begin{array}{l}\text { Bachelors } \\
\text { and above }\end{array}$ & $4(1.29)$ & $42(13.50)$ & $42(13.50)$ & $26(8.36)$ & $4(1.29)$ & $11.83 \pm 3.774$ & $\begin{array}{l}118 \\
(37.94)\end{array}$ \\
\hline $\begin{array}{l}\text { Not } \\
\text { responded }\end{array}$ & - & $8(2.57)$ & $6(1.93)$ & - & - & $10.43 \pm 2.593$ & $14(4.50)$ \\
\hline \multicolumn{8}{|l|}{ Occupation } \\
\hline $\begin{array}{l}\text { Banking/ } \\
\text { finance }\end{array}$ & - & $3(0.96)$ & $3(0.96)$ & - & - & $10.50 \pm 2.258$ & $6(1.93)$ \\
\hline Business & $2(0.64)$ & $8(2.57)$ & $10(3.22)$ & $6(1.93)$ & - & $11.65 \pm 3.919$ & $26(8.36)$ \\
\hline $\begin{array}{l}\text { Farming/ } \\
\text { agriculture }\end{array}$ & $2(0.64)$ & $6(1.93)$ & - & $3(0.96)$ & - & $9.27 \pm 4.519$ & $11(3.54)$ \\
\hline $\begin{array}{l}\text { Health } \\
\text { profession }\end{array}$ & - & $7(2.25)$ & $9(2.89)$ & $4(1.29)$ & $1(0.32)$ & $12 \pm 3.834$ & $21(6.75)$ \\
\hline Homemaker & - & $21(6.75)$ & $29(9.32)$ & $15(4.82)$ & $3(0.96)$ & $12.19 \pm 3.707$ & $68(21.86)$ \\
\hline $\begin{array}{l}\text { Manual/ } \\
\text { skilled } \\
\text { worker }\end{array}$ & - & $5(1.61)$ & $3(0.96)$ & $1(0.32)$ & $1(0.32)$ & $11.40 \pm 4.671$ & $10(3.22)$ \\
\hline $\begin{array}{l}\text { Office } \\
\text { worker/ } \\
\text { Service/ Job }\end{array}$ & $4(1.29)$ & $12(3.86)$ & $10(3.22)$ & $5(1.61)$ & - & $10.42 \pm 3.854$ & $31(9.97)$ \\
\hline Student & $2(0.64)$ & $21(6.75)$ & $30(9.65)$ & $18(5.79)$ & $4(1.29)$ & $12.51 \pm 3.663$ & $75(24.12)$ \\
\hline Teacher & $1(0.32)$ & $4(1.29)$ & $2(0.64)$ & $2(0.64)$ & $2(0.64)$ & $12.36 \pm 4.523$ & $11(3.54)$ \\
\hline Retired & $1(0.32)$ & $6(1.93)$ & $2(0.64)$ & $2(0.64)$ & - & $10.09 \pm 3.534$ & $11(3.54)$ \\
\hline Unemployed & $2(0.64)$ & $7(2.25)$ & $5(1.61)$ & $3(0.96)$ & - & $10 \pm 3.905$ & $17(5.47)$ \\
\hline Others & - & $3(0.96)$ & $3(0.96)$ & $1(0.32)$ & - & $11.29 \pm 3.147$ & $7(2.25)$ \\
\hline $\begin{array}{l}\text { Not } \\
\text { responded }\end{array}$ & - & $8(2.57)$ & $7(2.25)$ & $2(0.64)$ & - & $10.82 \pm 2.675$ & $17(5.47)$ \\
\hline
\end{tabular}

About demographics, the mean age of the participants was $37.40 \pm 16.208$ years (SEM $=0.919$ ) which ranged from nine years to 90 years and there were 143 $(45.98 \%)$ males and 168 (54.02\%) females. Since the study was conducted in Bagmati province, almost all the participants $(289,92.93 \%)$ were from Bagmati province and eight $(2.57 \%)$ did not respond.

\section{DISCUSSION}

Dental anxiety can be predicted by cancellation of dental appointment(s), memorisation of poor dental practice, gender, and age. ${ }^{5}$ Dental anxiety also varies with age, sex, and education. ${ }^{12}$ The MDAS is the modification of the Corah's Dental Anxiety Scale, which also includes question about local anaesthetic injection. Levin, et al. have reported that patients suffering from chronic periodontitis had higher anxiety compared to control group patients. ${ }^{13}$

The mean MDAS- $N$ score of all participants was $11.59 \pm 3.808$, this was similar to that reported by Faisal et al. (10.24 \pm 4.7$).{ }^{14}$ In this study, high dental anxiety (MDAS-N $\geq 19$ ) was observed in $11(3.54 \%)$ of the 311 participants. Other study showed $13 \%$ of patients in dental college and $20.90 \%$ of patients in dental clinics were severely anxious. ${ }^{3}$ One study reported that more than one third $(36.9 \%)$ of the study population had DAS $\geq 15$ (suggestive of highly anxious individuals). ${ }^{15}$ Another study done by telephone survey ${ }^{4}$ showed that $11.6 \%$ had high dental anxiety (DAS-N $\geq 19$ ) while White, et al. ${ }^{16}$ reported $6.82 \%$ patients with high dental 
anxiety. In this study, females were more anxious than males. Though most studies, ${ }^{5,6}$ report females to be more anxious, a study in South India did not support for gender differences for anxiety. ${ }^{7}$

In the present study, 0-19 years age group had highest mean score of $12.43 \pm 3.830$ (Table 3) similar to other study which showed $54.1 \%$ had severe dental anxiety, ${ }^{17}$ but Viinikangas, et al. study reported less score for older individuals. ${ }^{18}$ The prevalence of anxiety was seen mostly in the 20-30-year age group (37.3\%). ${ }^{19}$ The anxiety level can be decreased by dental screening and education. ${ }^{17}$ Medical and dental students were less anxious than arts and computer science students suggesting role of dental education in reducing dental anxiety. ${ }^{20,21}$

In current study, participants were more anxious on the day before appointment than on the day during waiting for an appointment where as in Inamdar, et al. study, the level of anxiety while waiting for a dental treatment, increased a little as compared to the anxious anticipation of dental treatment a day earlier, approximately $10 \%$ of the individuals were more anxious. ${ }^{15}$ In this study, MDAS score had been found the highest with local anaesthesia and tooth drilling where similar study done on students reported that students were anxious about tooth drilling and local anaesthetic injection. While anticipating a dental treatment for the next day, $35.3 \%$ of participants were not anxious. There were various levels of anxiety among the remaining $65.7 \%$. Total of $64 \%$ of these respondents were extremely anxious to slightly anxious. Anxiety levels increased further when participants were asked about getting their tooth drilled and $89 \%$ of the respondents were anxious about getting their tooth drilled. ${ }^{15}$ similarly, higher level of anxiety was found to be exhibited by participants for injection (55\%), followed by scaling $(45 \%)$ and tooth drilling $(40 \%) .{ }^{22}$
Local anaesthesia is given for other dental procedure and related to dental delayed dental visit. ${ }^{23}$ High anxiety, younger age, and traumatic dental history were correlated with greater increases in heart rate during the administration of local dental anaesthesia. ${ }^{24}$ dental education, psychotherapy might be helpful in reducing anxiety regarding local anaesthesia.

The mean MDAS-N score was highest $(11.83 \pm 3.774)$ among bachelors and above education group, but the difference was minimal (Table 4). This may be due to more awareness for oral health and it is multifactorial which is governed by social, cultural rituals and education. Anxiety is present in other patient category(dyspepsia and irritable bowel syndrome). ${ }^{25}$ No significant difference result have been found between death-related occupations (firemen, funeral personnel) and non-death related occupations (secretaries, accountants, teachers, etc.) measured by death related anxiety scale. ${ }^{26}$ Limitations of the study include singlecentre study with small sample size.

\section{CONCLUSIONS}

The prevalence of anxiety among patients visiting fot periodontal therapy in this study was found to be higher compared to other study done in similar setting. Further studies with other modifying variables are needed to conclude this finding regarding dental anxiety in periodontal therapy and its reduction for patient comfort.

\section{ACKNOWLEDGEMENTS}

We would like to acknowledge all the patients for their valuable feedback on dental anxiety. We would also like to thank Mrs. Sharmila KC for her motivation and support. We would like to thank institutional review committee of Kathmandu Medical College for approving for this study in our institute.

Conflict of Interest: None.

\section{REFERENCES}

1. Rubin JG, Krochak M. The psychodynamics of dental anxiety and dental phobia. Dent Clin North Am. 1988 Oct;32(4):647-56. [PubMed | Full Text]

2. Cohen LA, Snyder TL, LaBelle AD. Correlates of dental anxiety in a university population. J Public Health Dent. 1982;42(3):228-35. [PubMed | Full Text | DOI]

3. Ganesh R, Goswami C, Munshi R. Comparison of dental anxiety among patients visiting a dental college and private dental clinics in Thiruvallur district, India. SRM J Res Dent Sci. 2014;5(1):14-20. [Full Text | DOI]

4. Humphris GM, Dyer TA, Robinson PG. The modified dental anxiety scale: UK general public population norms in 2008 with further psychometrics and effects of age. BMC Oral Health. 2009;9(1):20-7. [ubMed | Full Text | DOI]

5. Ibrahim NK, Al-Jdani M, Al-Aamoudi N, Sukkar S. Anxiety due to dental procedures and treatment among adult patients attending outpatient clinics in King Abdulaziz University Hospital, Jeddah, Saudi Arabia. J Med Res. 2016;2(2):35-40. [Full Text]

6. Wali A, Ali SA, Siddiqui TM, Farzand M, Malik L. Assessment of anxiety in patients attending Baqai Dental Teaching Hospital Karachi-a cross sectional study. J Bahria Univ Med Dent Coll. 2019;9:34-7. [Full Text]

7. Appukuttan DP, Tadepalli A, Cholan PK, Subramanian S, 
Vinayagavel M. Prevalence of dental anxiety among patients attending a dental educational institution in Chennai, India--a questionnaire based study. Oral Health Dent Manag. 2013;12(4):289-94. [PubMed | Full Text]

8. Liu Y, Huang X, Yan Y, Lin H, Zhang J, Xuan D. Dental fear and its possible relationship with periodontal status in Chinese adults: a preliminary study. BMC Oral Health. 2015;15(1):18. [ubMed | Full Text | DOI]

9. Amir A, Kamate S, Gupta P, Gupta A, Singh J, Singh S. Assessment of dental anxiety using MDAS (modified dental anxiety scale) among students in Bareilly city-A cross sectional study. Int J Contemp Med Res. 2018;5(3):4-6. [ [Full Text]

10. Roy DK, Dixit PB, Ghimire S, Roy RK, Pandey A, Maharaj A. Dental anxiety and its possible effects on caries prevalence among group of dental students in Kathmandu medical college. J Nepalgunj Med Coll. 2019;17(2):78-81. [Full Text | DOI]

11. Giri J, Pokharel PR, Gyawali R, Bhattarai B. Translation and validation of modified dental anxiety scale: The Nepali version. Int Sch Res Notices. 2017 Jan 29;2017:5495643. [PubMed | Full Text | DOI]

12. Lahti S, Vehkalahti MM, Nordblad A, Hausen H. Dental fear among population aged 30 years and older in Finland. Acta Odontol Scand. 2007;65(2):97-102. [PubMed | Full Text | DOI]

13. Levin L, Zini A, Levine J, Weiss M, Lev R, Taub DC, et al. Demographic profile, oral health impact profile and dental anxiety scale in patients with chronic periodontitis: a casecontrol study. Int Dent J. 2018 Aug;68(4):269-78. [PubMed | Full Text | DOI]

14. Faisal S, Zehra N, Hussain M, Jaliawala HA, Faisal A. Dental anxiety among patients attending public and private dental hospitals of Karachi. J Pak Dental Assoc. 2015 Jan;24(01):46. [Full Text]

15. Inamdar A, Alwadaani M, Asiri A, Arishi A, Quadri M, Chokhandre M. Dental anxiety in medical and dental undergraduates at Jazan University. J Oral Health Res. 2013;4. [Full Text]

16. White AM, Giblin L, Boyd LD. The prevalence of dental anxiety in dental practice settings. J Dent Hyg. 2017 Feb 1;91(1):30-4. [PubMed | Full Text]

17. Shivanna V, Jain Y, Valluri R, Birra V, Kumar V, Ealla KKR.
Estimation of dental anxiety levels before and after dental visit in children with visual impairment using modified dental anxiety scale in braille text. J Int Soc Prev Community Dent. 2020;10(1):76-84. [PubMed | Full Text | DOI]

18. Viinikangas A, Lahti S, Yuan S, Pietilä I, Freeman R, Humphris G. Evaluating a single dental anxiety question in Finnish adults. Acta Odontol Scand. 2007;65(4):236-40. [PubMed | Full Text | DOI]

19. Marya CM, Grover S, Jnaneshwar A, Pruthi N. Dental Anxiety among Patients visiting a dental institute in Faridabad, India. West Indian Med J. 2012;61(2):187-90. [PubMed | Full Text]

20. Al-Omari WM, AL-Omiri MK. Dental anxiety among university students and its correlation with their field of study. J App Oral Sci. 2009;17(3):199-203. [라bMed | Full Text $\mid$ DOI]

21. Sghaireen MG, Zwiri AMA, Alzoubi IA, Qodceih SM, Al-Omiri MK. Anxiety due to dental treatment and procedures among university students and its correlation with their gender and field of study. Int J Dent. 2013;2013:647436. [PubMed | Full Text | DOI]

22. Sinha E, Rekha R, Nagashree S. Anxiety of dental treatment among patients visiting primary health centers. J Indian Assoc Public Health Dent. 2019;17(3):235-45. [Full Text | DOI]

23. Esmaeili H, Malekzadeh M, Esmaeili D, Nikeghbal F. Dental anxiety and the effectiveness of local anesthesia. Brazilian J Oral Sci. 2020;19:e208127. [Full Text | DOI]

24. Liau FL, Kok SH, Lee JJ, Kuo RC, Hwang CR, Yang PJ, et al. Cardiovascular influence of dental anxiety during local anesthesia for tooth extraction. Oral Surg Oral Med Oral Pathol Oral Radiol Endod. 2008;105(1):16-26. [PubMed | Full Text | DOI]

25. Hu WHC, Wong WM, Lam CLK, Lam KF, Hui WM, Lai $\mathrm{KC}$, et al. Anxiety but not depression determines health care-seeking behaviour in Chinese patients with dyspepsia and irritable bowel syndrome: a population-based study. Aliment Pharmacol Ther. 2002;16(12):2081-8. [ Full Text | DOI]

26. Lattanner B., Hayslip, B. Occupation-related differences in levels of death anxiety. OMEGA - J Death Dying.1985 Aug 1;15(1):53-66. [Full Text | DOI] 